\title{
Physicochemical Properties of Spray-Dried Young Coconut Juice
}

\author{
Pimolmart Rattanaburee ${ }^{1}$, Thanaporn Amnuaikit ${ }^{2}$, and Jindaporn Puripattanavong ${ }^{1}$ \\ ${ }^{1}$ Department of Pharmacognosy and Pharmaceutical Botany, Faculty of Pharmaceutical Sciences, Prince of Songkla \\ University, Songkhla, Thailand \\ ${ }^{2}$ Department of Pharmaceutical Technology, Faculty of Pharmaceutical Sciences,Prince of Songkla University, \\ Songkhla, Thailand \\ Email: jindaporn.p@psu.ac.th
}

\begin{abstract}
Objective: To evaluate physicochemical properties, antioxidant activity and phytochemical determinations of Young Coconut Juice (YCJ) from Cocos nucifera L. (Arecaceae) and spray-dried maltodextrin (MD) mixed YCJ powder (MD-YCJ powder).Methods: YCJ and spray-dried YCJ in various concentrations $0-20 \%(w / v)$ of MD were studied on physical properties, chemical properties, antioxidant activity and phytochemical determinations. Results: YCJ and reconstituted spray-dried YCJ were significant $(\mathbf{p}<0.05)$ difference in physicochemical properties (color, $\mathbf{p H}$, total soluble solids and transmittance).Water activity $\left(a_{w}\right)$ of spray-dried YCJ products were significant $(\mathbf{p}<0.05)$ difference. Antioxidant activity of YCJ and spray-dried YCJ in various concentrations $0-20 \%(w / v)$ of $M D$ were studied. The isolated compound of spray-dried YCJ and spray-dried MD-YCJ powder $(20 \%, w / v), \beta$-sitosterol, was separated, identified and confirmed by comparison of their physical properties (TLC, HPLC chromatogram, melting point). The quantitative analysis of $\beta$-sitosterol in YCJ and selected spray-dried YCJ powder (calculated as 1 coconut fruit, 350 ml) using suitable HPLC conditions were 89.12 \pm 7.76 and 12.31 $\pm 2.50 \mu \mathrm{g}$, respectively. Conclusion: Spray-dried technique was selected and used as drying process of YCJ. MD was used as encapsulating agent to dried powder. Spray-dried MD-YCJ powder $20 \%$ (w/v) was selected to future study because of their good physical appearance, physicochemical properties, antioxidant activity and good stability.
\end{abstract}

Index Terms-young coconut juice, spray-dried young coconut juice, physicochemical properties, antioxidant activity, phytochemical properties

\section{INTRODUCTION}

Young Coconut Juice (YCJ), the liquid endosperm of young coconut from Cocos nucifera L., Arecaceae, was obtained from aromatic green dwarf variety. YCJ is highly rich in nutritional (sugars, vitamins, minerals,

Manuscript received July 9, 201716, 2016; revised January 30, 2017. amino acids), phytochemical (polyphenol, phytosterols and phytohormones) [1] and therapeutic properties (antioxidant, antibacterial, antidote, hepatoprotective, hypoglycemic, cardioprotective, delaying osteoporosis, reduce risk of Alzheimer's disease, wound healing and estrogen-like effect [2]-[4]. YCJ has been prepared in dry form because of the storage and handling problems. Drying procession can be product manufacture of YCJ powder, for example freeze drying YCJ powder [5]. One of the most commonly drying process is spray drying, widely used in commercial production of milk powders, vegetable and fruits [6], [7]. Maltodextrin (MD), encapsulating agent, was use for encapsulate YCJ powder. In this study, YCJ, spray-dried YCJ powder and spraydried MD-YCJ powder were further studied on antioxidant activities, phytochemical, physical, and chemical properties.

\section{MATERIALS AND METHODS}

\section{A. Chemicals}

All the chemicals used in these experiments were analytical grade and purchased from Labscan Asia (Bangkok, Thailand). Maltodextrin DE 10(MD) was purchased from Zhucheng Dongxiao Biotechnology Co., Ltd., (China).

\section{B. Preparation of Young Coconut Juice}

Young Coconut Juice (Cocos nucifera L., Arecaceae) was obtained from aromatic green dwarf variety of fresh young coconut fruits (6-7 months) from Hat Yai District, Songkhla Province, Thailand. It was then pooled and analyzed within 48 hours after harvest. The clear YCJ was kept sealed in plastic bag and stored at $-20{ }^{\circ} \mathrm{C}$ before used.

\section{Preparation of Spray Dried Young Coconut Juice}

Encapsulation YCJ was prepared by mixed with MD in various concentrations $(0,5,10,15$ and $20 \%$, w/v), respectively. After that, spray drying process including dispersion process of the core material in entrapment material, follow by atomization and spray the mixture in hot air desiccant into a chamber. The YCJ encapsulated mixtures were sprayed and dried using Buchi Mini spray 
dryer B-191 (Switzerland). The spray dryer was operated inlet and outlet temperature at $150{ }^{\circ} \mathrm{C}$ and $67^{\circ} \mathrm{C}$, respectively. The air flow was $50 \mathrm{~mm}$ and feed rate was 3 $\mathrm{ml} / \mathrm{min}$. The percentage of yield was calculated. Spraydried YCJ powder and spray-dried MD-YCJ powder was collected and kept in well-closed container and protect from light at $-20{ }^{\circ} \mathrm{C}$ until further analysis.

\section{Evalution of Physical and Chemical Properites}

\section{1) Physical properites}

Color parameters (Hunter $\mathrm{L}^{*}, \mathrm{a}^{*}$ and $\mathrm{b}^{*}$ values) of YCJ, reconstitute spray-dried YCJ powder and reconstitute spray-dried MD-YCJ powder were determined using a spectrophotometer-colorimeter (HunterLab, ColorQuest XT, USA) and expressed as L*, $\mathrm{a}^{*}$ and $\mathrm{b}^{*}$ values. $\mathrm{L}^{*}$ as lightness from zero (black) to 100 (white); $\mathrm{a}^{*}$ as redness when positive, gray when zero, and greenness when negative and $b^{*}$ refers to yellowness when positive, gray when zero, and blueness when negative. These parameters were determined in triplicate.

\section{2) Chemical properites}

The chemical properties of YCJ, reconstitute spraydried YCJ powder samples were evaluated as follows. Total soluble solid was determined with refractometer (Precision instruments, England). Acid-base was analyzed using pH meter (Mettler-Toledo, Switzerland). Transmittance of all YCJ samples was determined using a spectrophotometer (HunterLab, ColorQuest XT, USA) at $610 \mathrm{~nm}$ (relative to distilled water) [8]. Water activity $\left(\mathrm{a}_{\mathrm{w}}\right)$ of spray-dried YCJ powder these samples were determined by using a water activity meter (Aqualab, Series, USA) at room temperature. All of examinations were determined in triplicate.

\section{E. Antioxidant Activity}

Antioxidant activities of reconstitute spray dried YCJ powder and spray-dried MD-YCJ powder were evaluated by DPPH radical scavenging assay. The DPPH radical scavenging activity was measured by the 2,2- diphenyl-1picrylhydrazil (DPPH) according to a modified method [9-10]. For the modified method, spray-dried YCJ powder and spray-dried MD-YCJ powder were dissolved in distill water and diluted for at least five dilutions. The solutions $(100 \mu \mathrm{l})$ were mixed to an equal volume of $6 \mathrm{x}$ 10 -5 M DPPH (in 70\% EtOH) in 96-well plate. After a 30 minute incubation period at room temperature, the mixture was measured in 96-well microplates (Power WaveX, Biotek) at the absorbance of $517 \mathrm{~nm}$. L (+) Ascorbic acid (RFCL Limited, India) was used as a positive control in the same condition. The result was calculated as the effective concentration of sample required scavenging DPPH by 50\% (EC50 value).

\section{F. Phytochemical Determinations}

\section{1) Extraction}

Fresh YCJ (350 ml) and reconstituted spray-dried YCJ powder $(10 \mathrm{~g})$ are extracted with $\mathrm{CH}_{2} \mathrm{CL}_{2}(5 \mathrm{X} 20 \mathrm{ml})$. Then, the pooled $\mathrm{CH}_{2} \mathrm{CL}_{2}$ extract was evaporated under reduced pressure to give dried crude $\mathrm{CH}_{2} \mathrm{CL}_{2}$ extract. This extracts are kept in well-closed containers protected from light before used [5].

\section{2) Isolation and identification}

Each sample of dried crude $\mathrm{CH}_{2} \mathrm{Cl}_{2}$ extract was purified by column chromatography (silica gel, $200 \mathrm{~g}$ ). Elution was accomplished with a gradient of nhexane/EtOAc/MeOH. A total of 200 fractions (fraction size $20 \mathrm{ml}$ ) were collected and combined on the basis of the TLC profiles after detection with UV lamp and 50\% sulfuric acid in EtOH spraying reagent. The isolated compound, $\beta$-sitosterol, was collected and identifies from previous study [5].

\section{3) Thin Layer Chromatography (TLC)}

The standard $\beta$-sitosterol $(2 \mu \mathrm{g})$ (in house, PSU, Thailand) and the $\mathrm{CH}_{2} \mathrm{CL}_{2}$ extract of YCJ and spray-dried YCJ $(500 \mu \mathrm{g})$ were dissolved in chloroform and then subjected to thin layer chromatography (Merck, Germany) using silica gel as stationary phase and hexane-ethyl acetate $(90: 10,80: 20,60: 40, \mathrm{v} / \mathrm{v})$ as mobile phase. After developed, the TLC plate was dried at room temperature and sprayed with $50 \%$ sulfuric acid in $95 \% \mathrm{EtOH}$ and subsequently heated at $80-100^{\circ} \mathrm{C}$ for 10 minute. Purple color spot appeared coinciding with those of standard samples of $\beta$-sitosterol.

\section{4) HPLC analysis}

HPLC analysis was performing follow as previous study [5]. The chromatographic condition was using Agilent 1100 series equipped with photodiode-array detector (PDA) and auto sampler (Palo Alto, CA). The chromatographic conditions were obtained using a Vertisep $^{\mathrm{TM}}$ USP C18 HPLC column $(150 \times 4.6 \mathrm{~mm}, 5 \mu \mathrm{m})$ (Vertical Chromatography Co., Ltd., Thailand) under isocratic conditions with $100 \% \mathrm{MeOH}$ as the mobile phase at the flow rate of $1.0 \mathrm{ml} / \mathrm{min}$. The quantification wavelength of detector was set at $208 \mathrm{~nm}$.

\section{G. Statistical analysis}

At least three replicate analyses were carried out and the results were report as means \pm SD. The data was statistically tested by one-way analysis of variance (ANOVA). Statistical significant difference was established at $\mathrm{p}<0.05$.

\section{RESUlTS AND DISCUSSION}

\section{A. Physical appearence}

The $\%$ yield of spray-dried YCJ powder and spraydried MD-YCJ powder at concentrations 5-20\% (w/v) are showed in Table I. The physical appearance of spraydried MD-YCJ powder at concentrations 10, 15 and $20 \%$ (w/v) was observing as homogenous white powder as show in Fig. 1. Spray-dried MD-YCJ powder $5 \%(\mathrm{w} / \mathrm{v})$ was not show because it melts, caking and agglomeration in 1 hour after storage at room temperature $\left(30 \pm 2^{\circ} \mathrm{C}\right)$. Due to the storage problems of YCJ, MD was used to encapsulated YCJ to dried powders and can storage at room temperature without melting and agglomeration. Spray-dried MD-YCJ powder $20 \%$ (w/v) was selected to future study because it cans storage at room temperature after 30 days. 

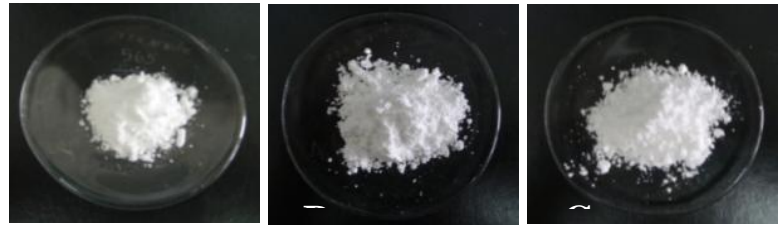

Figure 1. Spray-dried MD-YCJ powder at various concentrations A $10 \%, 15 \%, \mathrm{C} 20 \%(\mathrm{w} / \mathrm{v}$ of MD)

\section{B. Physicochemical determinations}

The physicochemical properties of YCJ and spraydried YCJ powder are showed in Table II. For the color measurement, the results of YCJ and reconstitute spraydried YCJ powder were significant $(\mathrm{p}<0.05)$ difference. Moreover, there were significant $(\mathrm{p}<0.05)$ difference in physicochemical properties including $\mathrm{pH}$ value, total soluble solids ( ${ }^{\circ}$ Brix), and transmittance between YCJ, reconstituted spray-dried YCJ powder and reconstituted spray-dried MD-YCJ powder. Water activity $\left(a_{w}\right)$ of spray-dried YCJ powder and spray-dried MD-YCJ powder were significant $(\mathrm{p}<0.05)$ difference. Water activity $\left(\mathrm{a}_{\mathrm{w}}\right)$ is an important factor affecting the stability of dehydrated products that was decrease when using MD as the material encapsulated for produce spray-dried YCJ powder and spray-dried MD-YCJ powder $20 \%$ (w/v) has lowest water activity. Spray-dried MD-YCJ powder $20 \%$ (w/v) was selected to future study because of the physical appearance, physicochemical qualities and good stability.

TABLE I. THE \% YIELD OF SPRAY-DRIED YCJ POWDER AND MD-YCJ POWDERS AT 5\% - 20\% (w/v)

\begin{tabular}{cc}
\hline Spray dried YCJ powder & \% yield \\
\hline YCJ powder & $1.05 \pm 0.58 \%$ \\
MD-YCJ powder 5\%(w/v) & $1.34 \pm 0.69 \%$ \\
MD-YCJ powder 10\%(w/v) & $5.76 \pm 1.07 \%$ \\
MD-YCJ powder 15\%(w/v) & $6.70 \pm 0.65 \%$ \\
MD-YCJ powder 20\%(w/v) & $7.33 \pm 1.29 \%$ \\
\hline
\end{tabular}

Each data represents the mean \pm S.D. $(n=3)$

TABLE II. PHYSICOCHEMICAL PROPERTIES OF YCJ, RECONSTITUTE SPRAY-DRIED YCJ POWDERSPRAY-DRIED YCJ POWDER AND SPRAY-DRIED MD-YCJ POWDERS AT $5 \%-20 \%(\mathrm{~W} / \mathrm{v})$

\begin{tabular}{|c|c|c|c|c|c|c|c|}
\hline \multirow{2}{*}{$\begin{array}{l}\text { Physicochemical } \\
\text { properties }\end{array}$} & \multirow{2}{*}{ YCJ } & \multicolumn{6}{|c|}{ Spray-dried MD-YCJ powder $(\%$, w/v) } \\
\hline & & $\mathbf{0}$ & 5 & 10 & 15 & 20 & $\begin{array}{l}\text { Ascorbi } \\
\text { c acid }\end{array}$ \\
\hline \multicolumn{8}{|l|}{ Color parameters } \\
\hline $\mathrm{L}^{*}$ value & $100.78 \pm 0.21^{\mathrm{a}}$ & $98.40 \pm 0.79^{\mathrm{b}}$ & $98.08 \pm 0.09^{\mathrm{b}}$ & $98.13 \pm 0.23^{\mathrm{b}}$ & $96.59 \pm 0.15^{\mathrm{c}}$ & $97.83 \pm 0.58^{\mathrm{b}}$ & - \\
\hline$a^{*}$ value & $-0.14 \pm 0.01^{\mathrm{a}}$ & $0.09 \pm 0.01^{\mathrm{b}}$ & $0.05 \pm 0.01^{\mathrm{c}}$ & $0.02 \pm 0.01^{\mathrm{d}}$ & $0.04 \pm 0.01^{\mathrm{c}}$ & $0.05 \pm 0.01^{\mathrm{c}}$ & - \\
\hline $\mathrm{b}^{*}$ value & $-0.12 \pm 0.01^{\mathrm{a}}$ & $0.58 \pm 0.01^{\mathrm{b}}$ & $1.12 \pm 0.01^{\mathrm{c}}$ & $1.12 \pm 0.01^{\mathrm{c}}$ & $1.09 \pm 0.01^{\mathrm{d}}$ & $1.12 \pm 0.01^{\mathrm{c}}$ & - \\
\hline $\mathrm{pH}$ value & $4.87 \pm 0.01^{\mathrm{a}}$ & $4.99 \pm 0.16^{\mathrm{b}}$ & $5.01 \pm 0.01^{\mathrm{b}}$ & $5.01 \pm 0.01^{\mathrm{b}}$ & $5.02 \pm 0.00^{\mathrm{b}}$ & $5.04 \pm 0.01^{\mathrm{b}}$ & - \\
\hline $\begin{array}{l}\text { Total soluble solid } \\
\left({ }^{\circ} \text { Brix }\right)\end{array}$ & $7.23 \pm 0.03^{\mathrm{ab}}$ & $7.98 \pm 1.81^{\mathrm{b}}$ & $12.02 \pm 0.13^{\mathrm{c}}$ & $15.08 \pm 0.08^{c}$ & $19.13 \pm 0.03^{\mathrm{bc}}$ & $22.05 \pm 0.05^{\mathrm{bc}}$ & - \\
\hline Transmittance (\%) & $97.89 \pm 0.34^{\mathrm{a}}$ & $96.56 \pm 0.88^{\mathrm{bc}}$ & $96.10 \pm 0.35^{\mathrm{c}}$ & $97.73 \pm 0.17^{\mathrm{a}}$ & $97.56 \pm 0.33^{\mathrm{ab}}$ & $96.58 \pm 0.88^{\mathrm{bc}}$ & - \\
\hline Water activity $\left(a_{w}\right)$ & N/A & $0.42 \pm 0.01^{\mathrm{a}}$ & $0.40 \pm 0.00^{\mathrm{b}}$ & $0.32 \pm 0.01^{\mathrm{c}}$ & $0.29 \pm 0.01^{\mathrm{d}}$ & $0.24 \pm 0.01^{\mathrm{e}}$ & - \\
\hline $\begin{array}{l}\text { Antioxidant activity } \\
\left(\mathrm{EC}_{50}\right)\end{array}$ & - & $\begin{array}{c}5.56 \pm 0.03 \\
(\mathrm{mg} / \mathrm{ml})\end{array}$ & $\begin{array}{c}9.23 \pm 0.03 \\
(\mathrm{mg} / \mathrm{ml})\end{array}$ & $\begin{array}{c}16.32 \pm 0.02 \\
(\mathrm{mg} / \mathrm{ml})\end{array}$ & $\begin{array}{c}27.16 \pm 0.04 \\
(\mathrm{mg} / \mathrm{ml})\end{array}$ & $\begin{array}{c}36.32 \pm 0.01 \\
(\mathrm{mg} / \mathrm{ml})\end{array}$ & $\begin{array}{c}3.25 \pm 0.0 \\
1 \\
(\mu \mathrm{g} / \mathrm{ml})\end{array}$ \\
\hline
\end{tabular}

N/A = not available.

Each data represents the mean \pm S.D. $(n=3)$.

$\mathrm{a}-\mathrm{d}$ : means in the same row with different superscript letter differ significantly $(\mathrm{p}<0.05)$.

\section{Antioxidant Activity}

The effective concentration of YCJ, spray-dried YCJ powder and spray-dried MD-YCJ powder 5-20\% (w/v) required to scavenge $\mathrm{DPPH}$ by $50 \% \quad\left(\mathrm{EC}_{50}\right.$ value) obtained by linear regression analysis of dose responds curve plotting between $\%$ inhibition and concentrations. Table II showed the $\mathrm{EC}_{50}$ value of YCJ, spray-dried YCJ powder and spray-dried MD-YCJ powder 5-20\% (w/v) that were decreased due to the amount of MD was increase. Spray-dried YCJ powder had many chemical constituents such as caffeic acid [11], (+)-catechin and ()-epicatechin [12], which affect the free radical scavenging activity of spray-dried YCJ powder. Antioxidant activities of polyphenolics derived from plants have claimed beneficial health functions for retarding aging and preventing cancer and cardiovascular diseases [13].

\section{Determination of Phytochemical Analysis}

After extraction, a $\beta$-sitosterol was isolated, identified and confirmed by comparison of their physical properties (TLC, HPLC, melting point (MP $=135-136^{\circ} \mathrm{C}$ )) and spectral data with those reported in the literature [5] [14].

The $\mathrm{CH}_{2} \mathrm{Cl}_{2}$ extract of YCJ, spray-dried YCJ powder and spray-dried MD-YCJ powder were subjected to thin layer chromatography. After developed, a spot showed pink color that coincided with that of the reference $\beta$ sitosterol. $\mathrm{R}_{\mathrm{f}}$ values of $\beta$-sitosterol isolated from the all samples were carried out with $\mathrm{R}_{\mathrm{f}}$ value of standard $\beta$ - 
sitosterol. $\mathrm{R}_{\mathrm{f}}$ values of $\beta$-sitosterol in three mobile phases were $0.13,0.29$ and 0.77 , respectively.

HPLC is a suitable analytical method for determining $\beta$-sitosterol in YCJ, reconstituted spray-dried YCJ and spray-dried MD-YCJ powder $20 \%$ (w/v).The HPLC chromatogram of $\beta$-sitosterol, YCJ and spray-dried MDYCJ powder $20 \%(\mathrm{w} / \mathrm{v})$ were performed in normal phase using $\mathrm{C} 18$ column as stationary phase and $\mathrm{MeOH}$ as mobile phase. The retention times of standard and samples were obtained in 16.2 - 16.5 minute. The quantitative analyses of $\beta$-sitosterol in YCJ and spraydried MD-YCJ powder $20 \%(\mathrm{w} / \mathrm{v})$ (calculated as 1 coconut fruit, $350 \mathrm{ml}$ ) using suitable HPLC conditions were 89.12 \pm 7.76 and $12.31 \pm 2.50 \mu \mathrm{g}$, respectively.

\section{CONCLUSION}

Spray-dried technique was used as drying process of YCJ. Maltodextrin was added for encapsulate YCJ. The spray-dried product of MD-YCJ was considered to be the good technique to dry YCJ on the result of phytochemical determination, physical and chemical properties and antioxidant activity.

\section{ACKNOWLEDGMENT}

Financial support from the Halal institute and Faculty of Pharmaceutical Sciences, Prince of Songkla University are gratefully acknowledged.

\section{CONFLICTS OF INTERESTS}

All authors have none to declare.

\section{REFERENCES}

[1] J. W. H. Yong, L. Ge, Y. F. Ng, and N. Tan, "The chemical composition and biological properties of coconut (Cocos nucifera L.) water," Mol., vol. 14, pp. 5144-5164, 2009.

[2] N. Radenahmad, et al., "Young coconut juice, a potential therapeutic agent that could significantly reduce some pathologies associated with Alzheimer's disease: Novel findings," Brit. J. Nutr., vol. 105, pp. 738-746, 2010.

[3] M. D. Mandal and S. Mandal, "Coconut (Cocos nucifera L.: Arecaceae): In health promotion and disease prevention," Asian Pac. J. Trop. Med., vol. 4, pp. 241-247, 2011.

[4] E. K. Nwangwa and C. P. Aloamaka, "Regenerative effects of coconut water and coconut milk on the pancreatic $\beta$-cells and cyto architecture in alloxan induced diabetic wistar albino rats," Pub. H., vol. 1, pp. 137-146, 2011.

[5] P. Rattanaburee, T. Amnuaikit, N. Radenahmad, and J. Puripattanavong, "Phytochemical study and its quantity and quality of fresh and freeze-dried Young Coconut Juice (Cocos nucifera L.)," Adv. Mat. Res., vol. 884-885, pp. 490-493, 2014.

[6] T. C. Kha, M. H. Nguyen, and P. D. Roach, "Effects of spray drying conditions on the physicochemical and antioxidant properties of the Gac (Momordica cochinchinensis) fruit aril powder," J. Food Eng., vol. 98, pp. 385-392, 2010.

[7] E. H. J. Kim, X. D. Chen, and D. Pearce, "Effects of surface composition on the flowability of industrial spray-dried dairy powders," Colloid Surface B., vol. 46, pp. 182-187, 2005.

[8] C. F. Campos, P. E. A. Souza, J. V. Coelho, and M. B. A. Gloria, "Chemical composition, enzyme activity and effect of enzyme inactivation of flavor quality of green coconut water," J. Food Process Pres., vol. 20, pp. 487-500, 1996.

[9] T. Hatano, H. Kagawa, T. Yasuhara, and T. Okada, "Two new flavonoids and other constituents in licorice root: Their relative astringency and radical scavenging effects," Chem. Pharm. Bull., vol. 36, pp. 2090-2097, 1998.
[10] K. Yamesaki, A. Hashimoto, Y. Kokusenya, T. Miyamoto, and T. Sato, "Electrochemical method for estimating the antioxidative effects of methanol extracts of crude drugs," Chem. Pharm. Bull., vol. 42, pp. 1663-1665, 1994.

[11] J. L. A. Santos, et al., "Evaluation of chemical constituents and antioxidant activity of coconut water (Cocos nucifera L.) and caffeic acid in cell culture," Anais Da Academia Brasileira De Ciências, vol. 85, pp. 1235-1246, 2013.

[12] C. L. Chang and R. T. Wu, "Quantitative of (+)-catechin and (-)epicatechain in coconut water by LC-MS," Food Chem., vol. 126, pp. 710-717, 2011.

[13] A. Scalbert, I. T. Johnson, and M. Saltmarsh, "Polyphenols: Antioxidants and beyond," Am. J. Clin. Nutr., vol. 81, pp. 215-217, 2005.

[14] L. Jahodar, V. Grygarova, and M. Budesinsky, "Triterpenoids of arctostaphylos uva-ursi roots," Pharmazie, vol. 83, pp. 442-443, 1998.

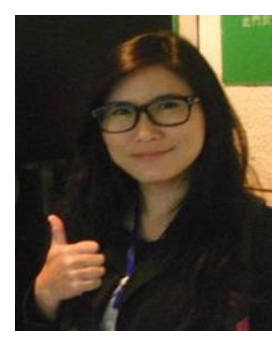

Pimolmart Rattanaburee was born in Nakhon Si Thammarat Province, Thailand, 2 December 1986. She got her B.Sc. in Thai Traditional Medicine, Prince of Songkla University, Thailand, 2008. She is a Ph.D. student at Department of Pharmacognosy and Pharmaceutical Botany,Faculty of Pharmaceutical Sciences, Prince of Songkla Universtiy, Hat-Yai Campus, Songkhla, Thailand. Her main paper is :

P. Rattanaburee, T. Amnuaikit, N. Radenahmad, and J. Puripattanavong, "Phytochemical study and its quantity and quality of fresh and freeze-dried Young Coconut Juice (Cocos nucifera L.)," Adv. Mat. Res., vol. 884-885, pp. 490-493, Jan 2014.

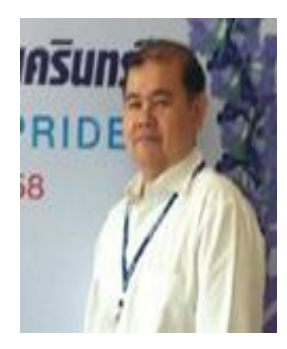

Jindaporn Puripattanavong was born in Surat Thani Province, Thailand, 17 January1965. He obtained his Ph.D. (Dr.rer.nat.) in Pharmaceutical Chemistry, University of Freiburg, Germany, 2000, M.S. in Pharmaceutical Botany, Chulalongkorn University, Thailand, 1991, and B.Sc. in Pharmaceutical Sciences, Prince of Songkla University, Thailand, 1988. At present, he is a Lecturer and Researcher at Department of Pharmacognosy and Pharmaceutical Botany, Faculty of Pharmaceutical Sciences, Prince of SongklaUniverstiy, HatYai Campus, Songkhla, Thailand. His main papers are:

J. Puripattanavong, P. Tungcharoen, P. Chaniad, S, Pianwanit, and Tewtrakul, "Anti-HIV-1 integrase effect of compounds from Aglaia andamanica leaves and molecular docking study with acute toxicity test in mice," Pharm. Biol., vol. 54, no. 4, pp. 654-659, 2016.

J. Puripattanavong and S. Tewtrakul, "Anti-allergic and antiinflammatory compounds from Aglaia andamanica leaves," Songklanakarin J. Sci. Technol., vol. 37, no. 1, pp. 37-41, Jan.-Feb. 2015.

J. Puripattanavong, T. Amnuaikit, N. Radenahmad, and P. Rattanaburee, "Phytochemical study and its quantity and quality of fresh and freeze-dried Young Coconut Juice (Cocos nucifera L.)," Adv Mat Res., vols. 884-885, pp. 490-493, Jan 2014.

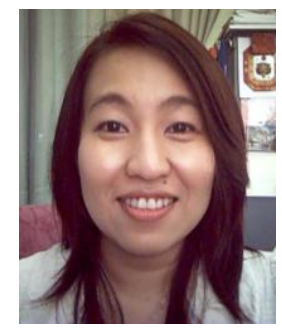

Thanaporn Amnuaikit was born in Songkhla Province, Thailand, 11 November 1974. She got her Ph.D. in Biotechnological and Pharmaceutical Sciences, Okayama University, 2005, M.S. in Pharmaceutical Manufacturing, Chulalongkorn University, Thailand, 2001, and B.Sc. in Pharmacy, Chiangmai University, Thailand, 1997. She is a Lecturer and Researcher at Department of Pharmaceutical Technology, Faculty of Pharmaceutical Sciences, Prince of SongklaUniverstiy, Hat-Yai Campus, Songkhla, Thailand. Her main papers are: 
T. Limsuwan, P. Boonme, and T. Amnuaikit, "Effect of phospholipid and ethanol concentrations on physical properties and stability of phenylethyl resorcinol loaded ethosome," Lat. Am. J. Pharm., vol. 35 , no. 7, pp. 1651-1656, 2016.

J. Buruschat and T. Amnuaikit, "Preparation of phenylethyl resorcinol niosomes for cosmetic formulation: Effects of Brij ${ }^{\mathrm{TM}} 72$ and cholesterol," Lat. Am. J. Pharm., vol. 35, no. 7. pp. 1640-1644, 2016.
P. Boonme, J. Kaewbanjong, T. Amnuaikit, and E. B. Souto, "Validation of HPLC method for quantitative determination of clotrimazole in microemulsion and microemulsion based gel," Lat. Am. J. Pharm., vol. 35, pp. 1222-1227, 2016. 